NBER WORKING PAPER SERIES

\title{
IMPLICATIONS OF CORPORATE CAPITAL STRUCTURE \\ THEORY FOR BANKING INSTITUTIONS
}

\author{
Yair E. Orgler \\ Robert A. Taggart, Jr. \\ Working Paper No. 737 \\ NATIONAL BUREAU OF ECONOMIC RESEARCH \\ 1050 Massachusetts Avenue \\ Cambridge MA 02138
}

August 1981

This paper was written while the first author was Visiting Professor of Finance at Northwestern. We are grateful to Northwestern's Banking Research Center for financial support and to Lemma $W$. Senbet for helpful comments on an earlier draft. The research reported here is part of the NBER's research program in Financial Markets and Monetary Economics. Any opinions expressed are those of the authors and not those of the National Bureau of Economic Research. 


\section{ABSTRACT}

This paper applies some recent advances in corporate capital structure theory to the determination of optimal capital in banking. The effects of corporate and personal taxes, government regulation, the technology of producing deposit services and the costs of bankruptcy and agency problems are all discussed in the context of the U.S. commercial banking system. The analysis suggests explanations for why commercial banks tend to have relatively less capital than nonfinancial firms, why commercial bank leverage has tended to increase over time and why large banks tend to have relatively less capital than small banks.

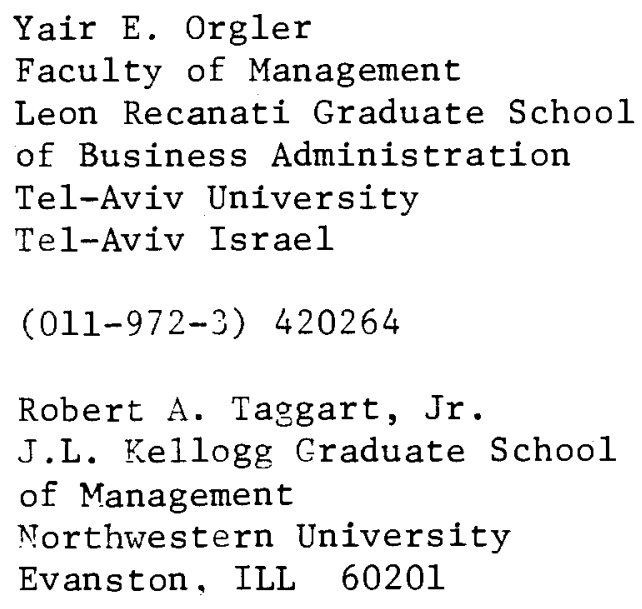




\section{Implications of Corporate Capital \\ Structure Theory for Banking Institutions}

The determination of an optimal capital structure for commercial banks has for many years stirred discussion and controversy among scholars, bankers and regulators. Numerous studies (Peltzman [16], Pringle [17], Mingo [14], Santomero and Watson [19], Taggart and Greenbaum [22], and Buser, Chen and Kane [4], to name a few) have explored theoretical and empirical aspects of bank capital, but the underlying issues have not been conclusively resolved.

At the same time the issue of optimal capital structure has seen a resurgence of interest in the corporate finance literature. In recent years, the effects on corporate capital structure of the tax system (Miller [12]), agency costs (Jensen and Meckling [9], Smith and Warner [21]), and bankruptcy costs (Haugen and Senbet [8]), as well as the combined effects of these factors (DeAngelo and Masulis [5], Barnea, Haugen and Senbet [1]), have all come under scrutiny.

While these studies in corporate finance have by no means resolved all the issues either, progress has been made and it seems worthwhile to analyze the implications of these advances for commercial bank capital structure. To be sure, several previous papers (Taggart and Greenbaum [22], Fama [7], and Buser, Chen and Kane[4], for example) have taken the view that banks are corporations and are thus susceptible to corporate capital structure theory. The full range of recent developments in this theory, however, has not yet to our knowledge been brought to bear on the 
bank capital decision.

The purpose of this paper is to analyze the implications for commercial banks of the new developments in capital structure theory. Specifically, we evaluate and attempt to explain the marked difference in leverage between banks and nonfinancial institutions on the basis of differences in the fundamental characteristics of their financial 1iabilities and in the level of regulation and supervision to which they are subject. The same framework will be used to analyze the differences in leverage between large and small banks.

In Section 1 below we briefly review recent work in corporate finance theory on the capital structure effects of taxes and agency costs. In Section II we discuss the effects of the interaction between the tax system and the production function for financial services on commercial bank capital structures. In Section III we analyze the nature of bankruptcy and agency costs in banking and their potential influence on bank capital. Finally, in Section IV we summarize and draw conclusions from our analysis.

I. Taxes, Agency Costs and Capital Structure in Corporate Finance Theory

Until just a few years ago, there appeared to be an evolving consensus among corporate finance scholars that the primary determinants of the optimal capital structure for a firm were corporate taxes and bankruptcy costs. Because interest payments are tax-deductible and dividend payments are not, debt financing was viewed as having a tax advantage over equity, and in the absence of any offset, debt would be the dominant form of financing. Increased use of debt, however, entails an increased risk of bankruptcy, which in turn imposes costs on the firm. Not only is the bankruptcy 
process itself costly because of legal and negotiating costs, but even an imminent threat of bankruptcy may be costly because it disrupts normal relationships with suppliers and customers and may force changes in the firm's investment and financing plans. The prevailing view, then, was that an optimal capital structure is reached when the present value of tax savings from an additional dollar of debt is just offset by the present value of marginal bankruptcy costs. ${ }^{1}$ Furthermore, since the nature of bankruptcy costs and the firm's susceptibility to them are specific to the individual firm, these costs were viewed as the primary determinants of differences in capital structures among a cross section of firms. This prevailing view has been increasingly challenged, however. It has been argued that bankruptcy costs are not sufficiently important either empirically (Warner [23]) or theoretically (Haugen and Senbet [8], to offset the tax saving from debt. lioreover, Jensen and Meckling [9], have pointed out that if tax savings are the only advantage to debt, then equity should be the dominant form of financing in the absence of corporate taxes. Since this implication is clearly refuted by pre-1913 empirical observation, they have constructed an alternative theory based on the notion that an owner-manager of a firm must enter into costly agency relationships with outside security holders, be they bondholders or shareholders. Finally, Miller [12] has questioned the importance that has been attributed to the tax-deductibility of interest. He has argued that once personal taxes on both ordinary income and capital gains are considered, the individual firm's capital structure may be a matter of indifference at a market equilibrium. 
Since Miller's argument and the agency cost theory play an important role in our own analysis, it is useful to review their essential features. To take the simplest version of Miller's model, consider a world of certainty in which investors choose among corporate bonds, paying an interest rate $R$, tax-exempt bonds, paying an interest rate $R_{o}$, and corporate stock. Investors pay taxes on income from corporate bonds at the rate $t_{\mathrm{pb}}^{i}$, where $t_{\mathrm{pb}}^{i}$ may differ across individuals in different tax brackets. Income from corporate stock, on the other hand, like that from tax-exempt bonds, is assumed to be free of personal taxes. In addition, corporations pay taxes on profits at the rate $t_{c}$.

If a corporation retires a dollar of debt it saves $R$ in interest payments, so that $R\left(1-t_{c}\right)$ can be channeled (after taxes) to its shareholders. Since shares are tax-exempt, the opportunity cost of income from shares is $R_{o}$, and shareholder wealth would be unchanged by this operation as long as $R\left(1-t_{c}\right)=R_{0}$. Value-maximizing firms will thus have a perfectly elastic supply of debt at the interest rate level $R=R_{o} /\left(1-t_{c}\right)$, because debt and equity can be freely substituted for one another at this level without affecting the firms' market values.

The aggregate demand for corporate bonds by investors, on the other hand, will rise with $\mathrm{R}$. As long as tax arbitrage operations are prohibited (or at least made costly), corporations as a whole will be able to sell more bonds only by driving up interest rates sufficiently to coax investors in successively higher tax brackets to hold them. The resulting equilibrium has been depicted by Miller (1977) with the diagram shown in Figure 1 , in which the aggregate amount of corporate debt, $B^{*}$ is determinate. 
$B^{*}$ is that level of debt sufficient to drive the interest rate on corporate bonds up to $\mathrm{R}_{\mathrm{o}} /\left(1-\mathrm{t}_{\mathrm{c}}\right)$. Once that aggregate amount of debt has been issued, however, any individual firm will be indifferent to further changes in its capital structure.

Any costs associated with corporate debt, such as bankruptcy costs or agency costs, can also be incorporated in this framework, as has been done by Barnea, Haugen and Senbet [1]. Since bankruptcy and agency costs make sense only in the presence of uncertainty, however, all rates of return must now be interpreted as certainty equivalents. Increased use of debt not only increases the chance of default, but as a consequence it exacerbates the incentive problems that arise between bondholders and shareholders. This, in turn, requires increasingly costly negotiation and monitoring activities, and the level of interest rates at which the firm is indifferent between debt and equity financing will no longer be constant. Rather, as the agency costs of debt rise relative to those of equity, the interest rate on corporate debt must fall relative to the cost of equity (here, the certainty equivalent of the tax-exempt bond rate) in order for the firm to be willing to supply an additional dollar of debt. ${ }^{2}$ The equilibrium amount of corporate debt will thus be as depicted in Figure $2 .^{3}$ Here there is again an optimal amount of corporate debt in the aggregate, but unlike the case considered by Miller there will also be an optimal capital structure at the firm level. Agency costs are firm-specific, and thus the interest rates at which different firms would be willing to supply a given amount of debt will differ. The aggregate supply curve of corporate bonds must be thought of as a horizontal sum of individual firm supply 
curves. Supply and demand at the aggregate level determine the interest rate on corporate bonds, and given this rate individual firms determine their optimal capital structures.

\section{Taxes and Commercial Bank Capital Structure}

\section{A. A Simple Miller-Type Model of Bank Capital}

With these developments in corporate capital structure theory in mind, we now turn to the capital decision in commercial banks. For the sake of clarity we will first analyze the impact of tax considerationsalone on this decision, deferring until the next section any discussion of agency problems. We begin with a simple model analogous to that of Miller [12].

Assume that there is no uncertainty. Commercial banks finance themselves by issuing either equity or a single type of deposit, which we will think of as a savings deposit. As in Miller's model, banks pay corporate taxes, but the return to investors on their equity is exempt from taxes at the personal level. The return, $R$, on bank deposits has two components. The first is explicit interest, $R_{D}$, which is taxable to investors at the rate $t_{\mathrm{pb}}^{i}$. For the time being we assume that $\mathrm{R}_{\mathrm{D}}$ is unrestricted by regulators (that is, we assume away regulation Q). ${ }^{4}$ The second component of $\mathrm{R}$ is some amount, $\mathrm{S}$, of services (per dollar of deposits) that are not taxable to investors. Each unit of services might be thought of as a package of bookkeeping, liquidity and safekeeping services, and the value of these services to the marginal depositor will be denoted by $V(S){ }^{5}$ It is also assumed for simplicity that banks levy no explicit charge upon depositors for these services.

The cost to an individual bank of providing these services depends on the quantity of services provided per dollar of deposits and on the 
bank's deposit level. Cost curves for individual banks may then be summed horizontally to obtain an aggregate cost curve, $C=C(S, D)$, where $S$ is the level of services per dollar of deposits and $D$ is the aggregate deposit level. The deposit market is competitive and, for simplicity, the quantity of services per dollar of deposits is taken to be fixed. The more realistic situation in which service levels and service charges are allowed to vary is considered further in Section II.B. Investors in this model may choose between corporate equity, taxexempt bonds and bank deposits. ${ }^{6}$ The focus here will be on the tradeoff between deposits and equity holdings, which, like tax-exempt bonds, bear a return of $R_{0}$. The demand curve for deposits represents the level of gross return, $R$, on deposits necessary to induce investors to hold a given quantity, D, of deposits. It is implicit that as holdings of deposits increase, holdings of equity are reduced. Since the demand curve is thus the locus of combinations of $R$ and $D$ for which the marginal investor would be just willing to substitute deposits for equity, this investor's marginal after-tax return on deposits, $R_{D}\left(1-t_{p b}^{i}\right)+V(S)$ must be equal to the return on equity, $\mathrm{R}_{\mathrm{o}}$, anywhere along the curve. Hence at any point on the curve, both

$$
R=R_{D}+V(S)
$$

and

$$
R_{D}\left(1-t_{p b}^{i}\right)+V(S)=R_{0}
$$

must hold. Eliminating $R_{D}$ from (1) and (2) gives 


$$
R=\frac{R_{0}}{1-t_{p b}^{i}}-V(S)\left(\frac{t_{p b}^{i}}{1-t_{p b}^{i}}\right)
$$

Note that without the service element, which is unique to bank deposits, $\mathrm{V}(\mathrm{S})=0$, and the above equation is identical to Miller's demand curve. As with the taxable bonds in Miller's model, banks can issue more deposits by paying a higher rate, $R_{D}$, so as to appeal to investors in successively higher tax brackets. The slope of the demand curve is thus

$$
\frac{d R}{d D}=\left(\frac{R_{0}-V(S)}{\left(1-t_{p b}^{i}\right)^{2}}\right)\left(\frac{d t_{p b}^{i}}{d D}\right)-\left(\frac{t_{p b}^{i}}{\left(1-t_{p b}^{i}\right)}\right)\left(\frac{d V(S)}{d D}\right),
$$

where $\mathrm{dt}_{\mathrm{pb}}^{\mathrm{i}} / \mathrm{dD}$ is positive. The first term in (4) is thus positive as long as $R_{D}$ is positive (see (2)). Since the marginal value of services would be expected to decline as investors receive more of them, we would also expect the second term to be positive and thus the demand curve will have a positive slope.

Expression (4) may be further interpreted by noting that if the entire return on deposits were paid in the form of explicit interest, we would have

$$
\frac{d R}{d D}=\left(\frac{R_{o}}{\left(1-t_{p b}^{i}\right)^{2}}\right)\left(\frac{d t_{p b}^{i}}{d D}\right)
$$

If the decline in the marginal value of services, $\mathrm{dV}(\mathrm{S}) / \mathrm{dD}$, is not too large as more deposits are issued, then expression (4) will be smaller than expression (5). That is, the gross return need not rise as much to 
attract more depositors in expression (4), because a part of that return comes in non-taxable form. Expression (5) by contrast, is exactly analogous to Miller's model, in which the interest rate is "grossed up" to pay the taxes of successively higher tax-bracket investors.

A bank's supply curve for deposits represents the levels of $R$ necessary to induce the bank to substitute various amounts of deposits for equity. Since the cost of equity is $R_{o}$, the height of the supply curve is that level of $R$ such that the after-tax marginal cost of deposits is equal to $R_{0}$. That is, we must have simultaneously

$$
R=R_{D}+V(S)
$$

and $R_{D}\left(1-t_{C}\right)+\partial C(S, D)\left(1-t_{C}\right) / \partial D=R_{0}$,

or, eliminating $\mathrm{R}_{\mathrm{D}}$,

$$
R=\frac{R_{0}}{1-t_{c}}-\frac{\partial C(S, D)}{\partial D}+V(S)
$$

Again, without the service element this equation is identical to Miller's supply curve. The shape of the supply curve depends largely on the costs of providing services. The intercept is at

$$
R=\frac{R_{o}}{1-t_{c}}-\partial C(S, 0) / \partial D+V(S),
$$

and the slope (assuming no individual bank perceives that it has any 
effect on $V(S)$ is

$$
\frac{d R}{d D}=-\partial^{2} C / \partial D^{2}
$$

Hence the slope will be positive negative or flat, depending on whether the marginal cost of producing services per dollar of deposits is falling, rising or constant. Moreover, if there is a range of deposits over which marginal costs decline, the bank would be willing to increase its explicit interest payments in order to attract these additional deposits.

The resulting equilibrium in the deposit market is depicted in Figure 3. As in Miller's model, the equilibrium aggregate amount of bank deposits, $\mathrm{D}^{*}$, is determined by the intersection of supply and demand. Unlike Miller's model, however, the costs of producing deposit services are specific to individual banking firms and thus, apart from the case of constant returns to scale, the industry equilibrium will also imply an equilibrium output of deposits for each bank.

Several implications for the relative degree of commercial bank leverage may be drawn from this model. First, to the extent that payment of part of the gross return on bank deposits in the form of non-taxable services tends to flatten the deposit demand curve, banks will be more highly levered than if their total return were paid in the form of taxable interest. ${ }^{7}$ This is depicted in Figure 4.

Second, the imposition of various regulatory costs on banks will shift the supply curve and, ceteris paribus, will tend to reduce bank leverage. A reserve requirement of $r$ per dollar of deposits, for example, acts as a tax upon banks for supplying deposits. Raising a dollar of 
loanable funds through deposits will now entail an effective cost of $\mathrm{R} / 1-\mathrm{r}$ and the supply curve will now be given by

$$
R=\frac{R_{0}(1-r)}{1-t_{c}}-\frac{\partial C(S, D)}{\partial D}+V(S)
$$

That is, imposition of a reserve requirement on deposits results in a parallel downward shift in the supply curve, which consequently reduces the equilibrium degree of commercial bank leverage.

Finally, the degree of bank leverage will depend on the extent of any range of economies of scale in the production of deposit services. Generally, the sooner the range of increasing marginal costs sets in, the sooner the supply curve will intersect the demand curve and the lower will be the equilibrium level of deposits. In the presence of entry regulation, moreover, the same applies at the individual bank level. In a fully competitive regime competition would drive out all inefficient producers of deposit services and in equilibrium only banks with identical minimum average costs could survive. If regulation erects entry barriers for the lower-cost producers, however, other banks will remain in business, but their equilibrium capital structures will be different from those of the lower-cost banks. This situation is depicted in Figure 5, in which supply curves for banks $A$ and $B$ are shown. ${ }^{8}$ The industry supply curve is the horizontal sum of all individual bank supply curves, and the intersection of industry demand and supply determines $R^{*}$, the equilibrium gross return on deposits. The optimal degree of leverage for each individual bank is then determined by the level of deposits on its own supply curve corresponding to $\mathrm{R}^{*}$. Degrees of leverage will differ in general among banks. 
In particular, if marginal costs of producing deposit services turn upward for smaller banks at lower degrees of leverage than for bigger banks, smaller banks will tend to be less highly levered. ${ }^{9}$

\section{B. Extensions of the Simple Model}

Perhaps the most obvious way that the model of Section II.A. might be extended is to take account of the variety of liabilities ordinarily issued by commercial banks. Rather than confining themselves to a single type of deposit, banks simultaneously issue demand deposits, Now accounts, passbook savings deposits and large and small scale time deposits of varying maturities. In addition, many banks make use of more conventional debt financing. The primary differences among these liabilities are the varying combinations of services and explicit interest that they represent.

Conventional debt and large-scale $\mathrm{CD}^{\prime}$, for example, pay investors a return that is largely in the form of explicit interest with minimal service packages. These liabilities would be most like the corporate bonds analyzed in Miller's model, and the same basic principles would apply. In the absence of bankruptcy or agency costs, tax considerations alone would dictate a horizontal supply curve for these liabilities, and their equilibrium quantity would be determinate at the aggregate level, but not at the level of the individual bank.

The other types of deposits are distinguished primarily by the service packages they offer, with checking accounts representing the most serviceintensive variety. Essentially, these different types of deposits, as well as the different minimum balance versus fee arrangements available within deposit categories, represent attempts to separate the demand curve for deposits, as described in Section II.A., into a number of separate markets, 
each appealing to different depositor characteristics. A deposit account with no explicit interest payments but large quantities of "free" services per dollar of deposits, for example, would appeal to both high tax bracket investors, because of the non-taxable nature of the return, and investors with high demands for these services. Deposit accounts with high explicit interest payments and separate charges for services, on the other hand, would appeal to both low tax-bracket investors and investors with low demands for services.

Further interpretation of banks' attempts to appeal to different depositor clienteles is provided if we think in terms of an overall demand for deposits that subsumes the various categories of accounts. Referring to Figure 4 and starting from the vertical axis, we could imagine the first increment of depositors as being willing to accept an account with low explicit interest and a minimal service package. Such an account would be acceptable to both depositors in very low tax brackets and/or those with a very strong desire for services. The next increment of depositors might be attracted by a slightly higher explicit interest payment, while the succeeding increment might be attracted by a slightly better service package. If moving up the demand curve in this fashion entails variations in both services and explicit interest, we would expect the demand curve to be flatter than if only explicit interest could be varied. In the model of Section II.A., additional depositors could be attracted only by raising $R_{D}$, but some of these depositors could have been attracted with smaller increments in the total return $R$ if the service component were also variable. The greater is banks' ability to tailor deposits to both the differing desires and tax brackets of investors, then, the flatter will be 
the overall demand curve and the greater will be the equilibrium degree of leverage for banks in the aggregate. 10

The variety of interest payments and service packages offered by banks would be determined on the supply side by both regulatory restrictions and technological feasibility. A ceiling on rates, such as Regulation $Q$, for example, would tend to encourage greater offerings of free services, but then the authorities may feel compelled to restrict amounts or types of services as well. Removal of ceilings would tend to encourage somewhat higher interest rates and greater use of service charges. $^{11}$ In terms of technical feasibility, the absence of all transaction costs or technological constraints might encourage banks to offer a different deposit contract to each and every customer, depending on his tax status and his desire for services. ${ }^{12}$ Since such extreme differentiation is infeasible, however, banks will trade off the extra profits from further differentiation against the costs of creating and keeping track of additional account categories.

The introduction of these different types of accounts complicates the details of the analysis and may bring to bear additional factors that are specific to individual banks on the determination of optimal capital structure. Nevertheless, the general character of the resulting equilibrium would still be the same as that described in the model of the preceding section. Supplies and demands would determine a constellation of gross rates of return on deposits and other liabilities of all types, and in equilibrium no bank would have any incentive to shift its liability mix. Cost conditions associated with the production of services (which may exhibit a considerable degree of jointness across different categories 
of deposits), reserve requirements against the various deposits and the shapes of the demand curves would be the primary determinants of the relative liability proportions.

Another extension of the basic model of the preceding section involves the role of deposit insurance. If we think of safety as one of the services banks provide to their depositors, we can view deposit insurance as a substitute for the production of safety by banks themselves. In the absence of deposit insurance, one would expect the benefits of diversification, both with respect to asset risk and withdrawal risk, to give larger banks an advantage over smaller banks in the production of safety. ${ }^{13}$ This would in turn imply that smaller banks would be less highly levered in equilibrium than larger banks. In Figure 5, for example, the supply curve for the smaller bank, A, might turn down sooner, because as A becomes more highly levered it is forced to invest in less risky assets in order to provide its depositors the same degree of safety. This in turn forces down the rate it can offer to depositors to raise more deposit funds. The larger bank $B$, on the other hand reaps diversification benefits and this allows it to be more highly levered.

With deposit insurance, however, the smaller bank's disadvantage in this respect is reduced. As long as its fee for insurance is a constant percentage of deposits, the smaller bank's supply curve will tend to flatten out, and the existence of insurance will thus tend to narrow the gap between the degree of leverage of large and small banks. The magnitude of this effect also depends on the proportion of large uninsured deposits out of total liabilities. While small banks usually do not have many uninsured deposits, their existence would tend to widen the leverage gap of large and small banks. Deposit insurance, of course, 
also has a number of incentive effects on bank behavior as we11 as effects on the costs of bankruptcy and liquidation. These will be discussed in more detail in Section III.

A further extension of the basic model of Section II.A. entails noting that bank equity is not in fact fully tax-exempt. If equity is subject to an effective tax rate $t_{p s}^{i}$, where $0 \leq t_{p s}^{i} \leq t_{p b}^{i}$, then the equation of the supply curve for deposits becomes

$$
R=\frac{R o}{\left(1-t_{c}\right)\left(1-t_{p s}^{i}\right)}-\frac{\partial C(S, D)}{\partial D}+V(S)
$$

The higher is $t_{\mathrm{ps}}^{i}$, the effective tax rate on stock returns for the marginal purchaser of corporate stock, the higher is the intercept of the supply curve. In turn, a parallel upward shift in the supply curve will tend, other things equal, to increase the degree of commercial bank leverage. Higher dividend payments by commercial banks, then, will tend to increase the effective tax rate on stock returns and will be associated with greater leverage. ${ }^{14}$ Our model offers no explanation, however, of bank dividend policy.

Finally, it should be noted that the role of the supply curve in our analysis is valid even in the absence of taxes, as long as the costs of producing bank services are lower than $\mathrm{V}(\mathrm{S})$. This may explain the relatively high leverage ratios in commercial banks that existed already at the beginning of this century. For instance, the ratio of capital to total bank assets was roughly 20 percent between 1900 and $1915^{15}$ As taxes were gradually increased, there was a parallel rise in bank leverage so 
that the ratio of capital to total assets for all U.S. commercial banks was 7.4 percent at the end of $1980 .^{16}$ While this increase in bank leverage can be attributed to other factors, such as increasing bank regulation and supervision, it is clear that the tax system had an important role in this development.

III. Bankruptcy Costs, Agency Costs and Commercial Bank Capital Structure Jensen and Meckling [9] list three categories of costs associated with debt: bankruptcy costs, the perverse incentive effects associated with highly levered firms, and the monitoring costs engendered by these incentive effects. In commercial banking, the form and magnitude of all three types of costs are intimately bound to the system of bank regulation and particularly the deposit insurance system. We will treat bankruptcy costs first and then turn to incentive and monitoring costs.

There is a general presumption that the probability of bankruptcy is lower in banking than in other industries. The reasons for this assumption are twofold: first, the degree of regulation and supervision by bank regulatory agencies is probably stronger than in any other industry, and it is expected that this tight control may reduce undue risks that could lead to bankruptcy. Second, it is widely believed that at least the largest banks will not be allowed to fail in order to avoid potentially serious damages to the monetary system. While there is no formal or even informal support for this assertion, the resolution of large bank failures in the 1970 's through assumption (takeover) rather than payoff (1iquidation) reenforces this belief. Consequently, large uninsured depositors could be expected to be less concerned about bankruptcy than 
corporate bondholders in other industries, and this may contribute to a reduction of indirect bankruptcy costs.

Direct bankruptcy costs are also likely to be lower for commercial banks than for nonfinancial corporations. In analyzing this issue it is helpful to make a distinction between liquidation and bankruptcy as was suggested by Haugen and Senbet [8]. Clearly, the cost of 1iquidating financial assets is lower than the cost of liquidating most real assets due to the existence of relatively efficient capital and money markets even at the local level. As far as direct bankruptcy costs are concerned, it can be argued that the existence of a specialized liquidation division within the FDIC is likely to reduce the various search, legal, bookkeeping and other costs and fees related to actual bankruptcy. In addition, the FDIC has coercive powers to impose a reorganization plan upon a failed bank, typically by having some other bank assume the failed bank's deposits. To the extent that this reduces negotiating costs and problems of one or more groups holding out on a reorganization plan in an attempt to increase their share of the proceeds, it may be that less damage is done to the going concern value of banks in bankruptcy than to other types of firms. The presence of deposit insurance also contributes to making deposits more perfectly substitutable across banks, and this may ease the transition problems associated with finding new management and maintaining continuity in existing customer relationships. For these reasons, marginal bankruptcy costs for a given degree of leverage may be less in the presence of banking regulation and the deposit insurance system than for nonfinancial firms, and banks may thus have a tendency to maintain higher degrees of leverage than these firms. 
Turning to the resolution of incentive problems, it is again apparent that the deposit insurance system plays a key part. It has been widely recognized (see Scott and Mayer [20], or Merton [11], for example) that the availability of deposit insurance at a fee that does not vary with the bank's risk of bankruptcy will exacerbate the perverse incentive problems associated with highly levered firms. Without any offsetting measures by the FDIC, in fact, banks would be likely to raise very little equity at all.

Buser, Chen and Kane [4] have argued, however, that the FDIC's regulatory authority, and in particular its ability to deprive a bank of future profits inherent in its charter, acts as an implicit risk-related deposit insurance premium. That is, short-term losses in an excessively levered bank could result in a temporarily negative net worth (in accounting terms) which, in turn, would force the FDIC to reorganize or liquidate the bank even if the present value of future profits is positive. Optimal bank capital is determined, therefore, by a tradeoff between tax savings and the implicit costs of regulatory interference.

Two points may be made concerning the Buser, Chen and Kane argument. The first is that it may be applied to a more broadly construed notion of agency problems, and this strengthens the prediction that banks will not be totally levered. Smith and Warner [21], have categorized four types of perverse incentives that a firm's shareholders may have to act against the interests of bondholders: substitution of riskier assets after the debt contract has been agreed upon, excessive payment of dividends, assuming liabilities of equal or higher priority to that of existing creditors, and underinvestment in profitable future opportunities. Each of these problems 
arise because the debt contract is not renegotiated even when the firm takes actions that would affect the market value of the debtholders' position. Thus the asset substitution, dividend payment and claim dilution motives arise because of opportunities to shift wealth from debtholders to shareholders. Similarly, the underinvestment incentive arises because the shareholders wish to avoid enhancing the debtholders' wealth at their own expense. If debt contracts were continuously renegotiated as the firm changed any of its policies, however, the value of the debt would be insulated from the effects of these changes, and shareholders would be motivated to take only those actions that enhance the net present value of the entire firm.

In commercial banking, the FDIC becomes the main claimant in the event of bankruptcy and it is thus in the FDIC's interest to take steps that will reduce the bank's incentive to erode the value of its position. Such steps include monitoring the risk of the bank's assets as well as its capital position, and in extreme cases closing the bank if the FDIC's position is unduly threatened. Thus, regulation and supervision of banks by the FDIC take the place of monitoring activities that might otherwise be undertaken by the bank's creditors. If the costs imposed on banks by this supervision increase as the risk of bankruptcy increases, as suggested by Buser, Chen and Kane, then the FDIC's activities also serve the same role as continuous renegotiation with debtholders. The bank's incentive to substitute assets, pay excessive dividends or dilute the debtholders claim by, say, reducing capital is reduced because any of these activities will cause implicit penalties to be imposed by the FDIC. By the same token, if the bank is implicitly rewarded by a lessening of these costs for adopting 
policies that bolster the value of the FDIC's claim, it will not have an incentive to underinvest in profitable future opportunities. In all, the FDIC's regulatory and supervisory activities can serve as a mechanism by which the costs of agency problems and bankruptcy are transmitted back to a bank's shareholders, and thus they help explain why a bank would not find it optimal to be totally levered.

The second point to be noted about this argument, however, is that it can cut two ways. While it may explain why commercial banks are not totally levered, it may also help explain why banks are nevertheless more highly levered than most types of firms. As has been noted above, the FDIC's activities are a substitute for analogous privatelyproduced monitoring and contracting activities. The FDIC's supervisory authority and its cooperation with other bank regulatory agencies may make these monitoring activities more efficient and more effective than would be possible among purely private creditors. Furthermore, to the extent that any of these monitoring costs are absorbed by society at large through the regulatory system, rather than the private parties to the deposit contract, greater leverage by banks may be encouraged.

To put the general thrust of this section into the context of the analysis of preceding sections, it is useful to refer back to Figure 2 . The Buser, Chen and Kane argument implies that the supply curve of deposits will have some downward slope because of the regulatory costs imposed on banks at higher degrees of leverage. Nevertheless, the nature of the FDIC's activities suggests that the downward slope of this supply curve will be more gentle than that of the supply curve for ordinary debt by a nonfinancial corporation. Hence we would expect that bankruptcy and agency cost considerations, similar to tax considerations, point to higher degrees of leverage for banks than for other types of firms. 
IV. Summary and Conclusions

The theory of corporate capital structure that has evolved in recent years provides a useful framework for analyzing bank capital structure. There are, however, several fundamental differences between commercial banks and nonfinancial firms that contribute to a large disparity in their degree of leverage.

The first major distinction between commercial banking and other industries is the nature of bank liabilities. Banks raise most of their funds in the form of deposits that offer different combinations of interest and services such as liquidity, safety, and bookkeeping. Since the cost of producing these services is tax deductible to the banks but the benefits from the services are tax free to the depositors, deposits have an obvious tax advantage over corporate bonds. Moreover, the production function of bank services is likely to have economies of scale properties that will further increase the aggregate equilibrium amount of outstanding deposits. Since service production costs are bank-specific, the resulting equilibrium will also determine optimal leverage for individual banks.

The second major difference between commercial banks and nonfinancial firms is the regulatory environment. Banks are probably more closely regulated and supervised than any other industry. This environment reduces both the probability and cost of bankruptcy for commercial banks. Moreover, the special function of deposit insurance creates a unique role for the FDIC as a major principal (in addition to shareholders) in all insured banks. The substantial regulatory and supervisory powers of the FDIC relative to private creditors of nonfinancial firms are likely to reduce agency costs. For instance, periodic bank examinations represent a monitoring device that 
may reduce asset substitution and other actions that could be taken by shareholders at the expense of depositors.

The combined effect of the tax-free service component in deposits and the reduced agency costs due to tougher regulation helps to explain the consistently higher degree of leverage observed in banks vis-a-vis nonfinancial firms. Moreover, the same framework could explain the fact that large banks traditionally have lower capital-to-asset ratios than small banks. This observation can be attributed to higher costs of producing bank services and to a higher perceived probability and cost of bankruptcy. The latter may be due to the greater incidence of liquidation for small failed banks compared with large bank failures. 


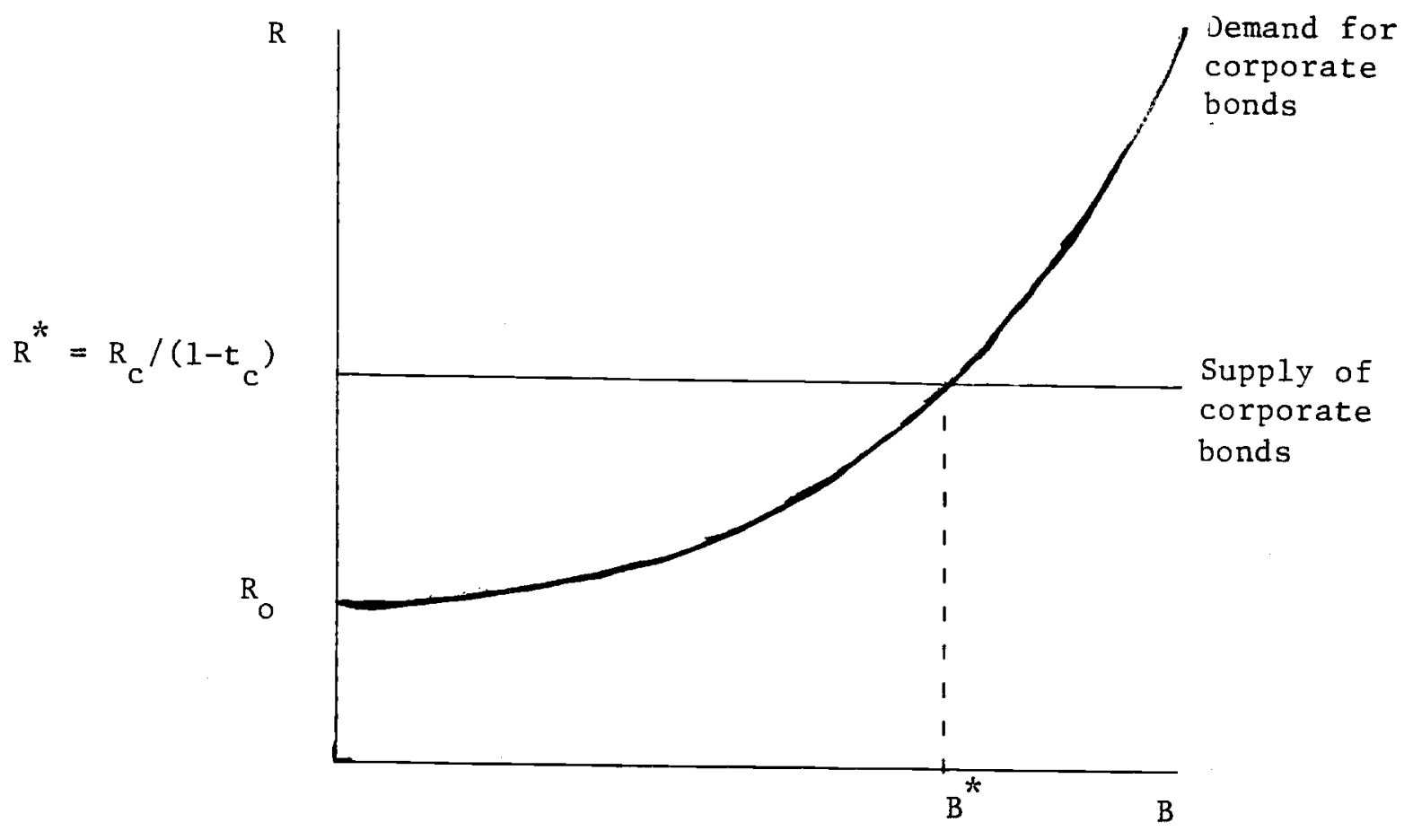

FIGURE 1

The Equilibrium Amount of Corporate Bonds in the Absence of Agency Costs 


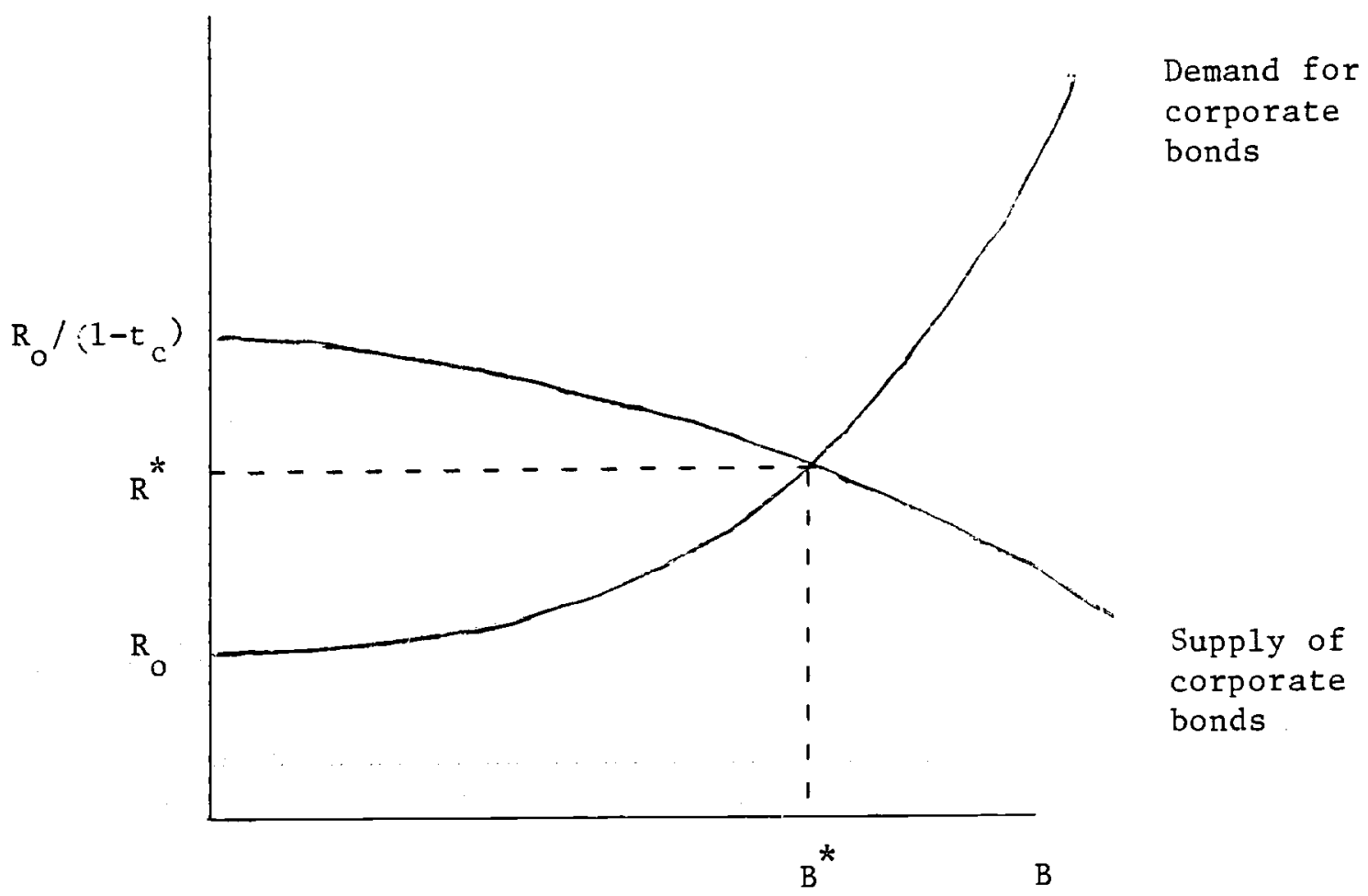

FIGURE 2

The Equilibrium Amount of Corporate Bonds in the Presence of Agency Costs 


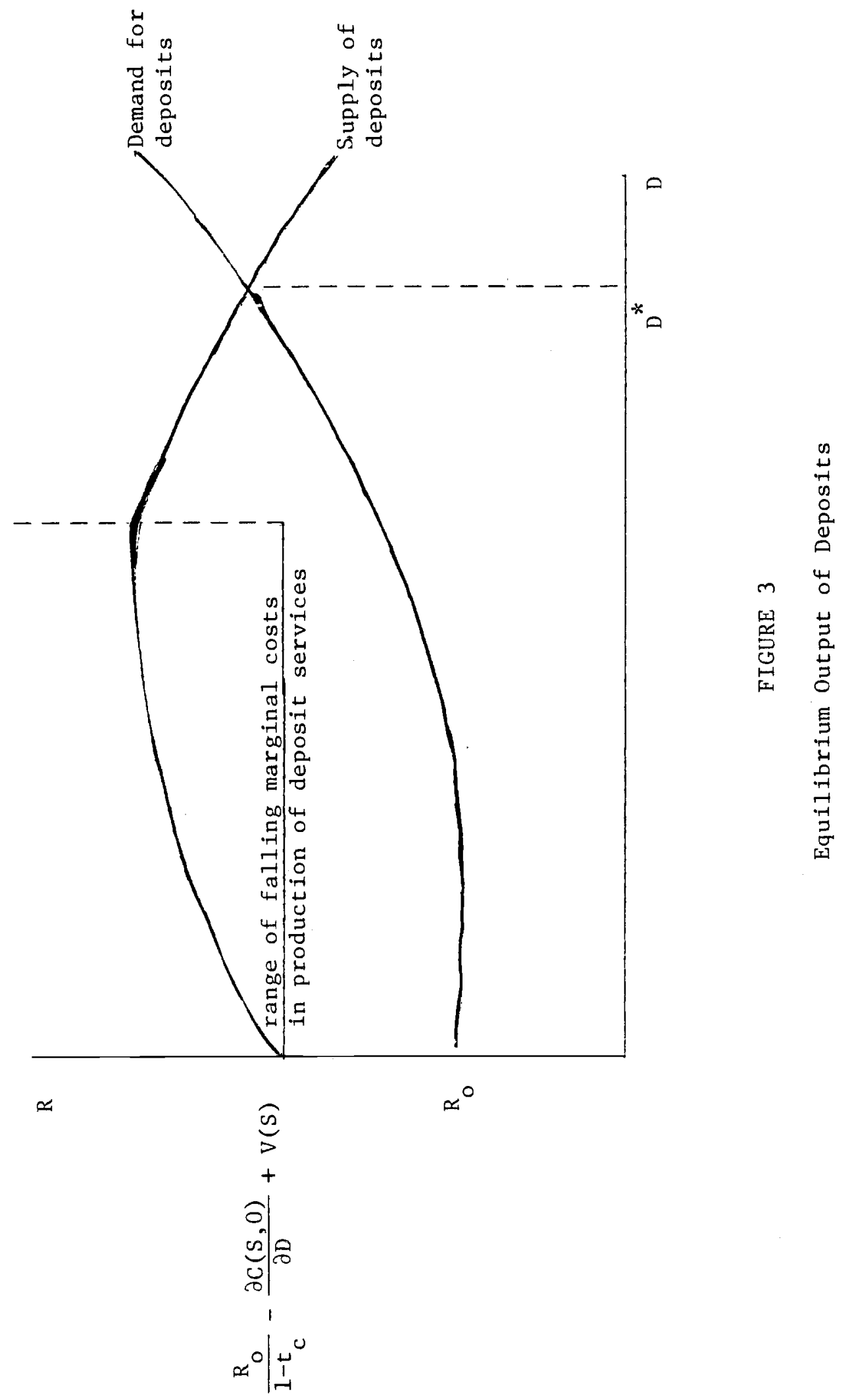




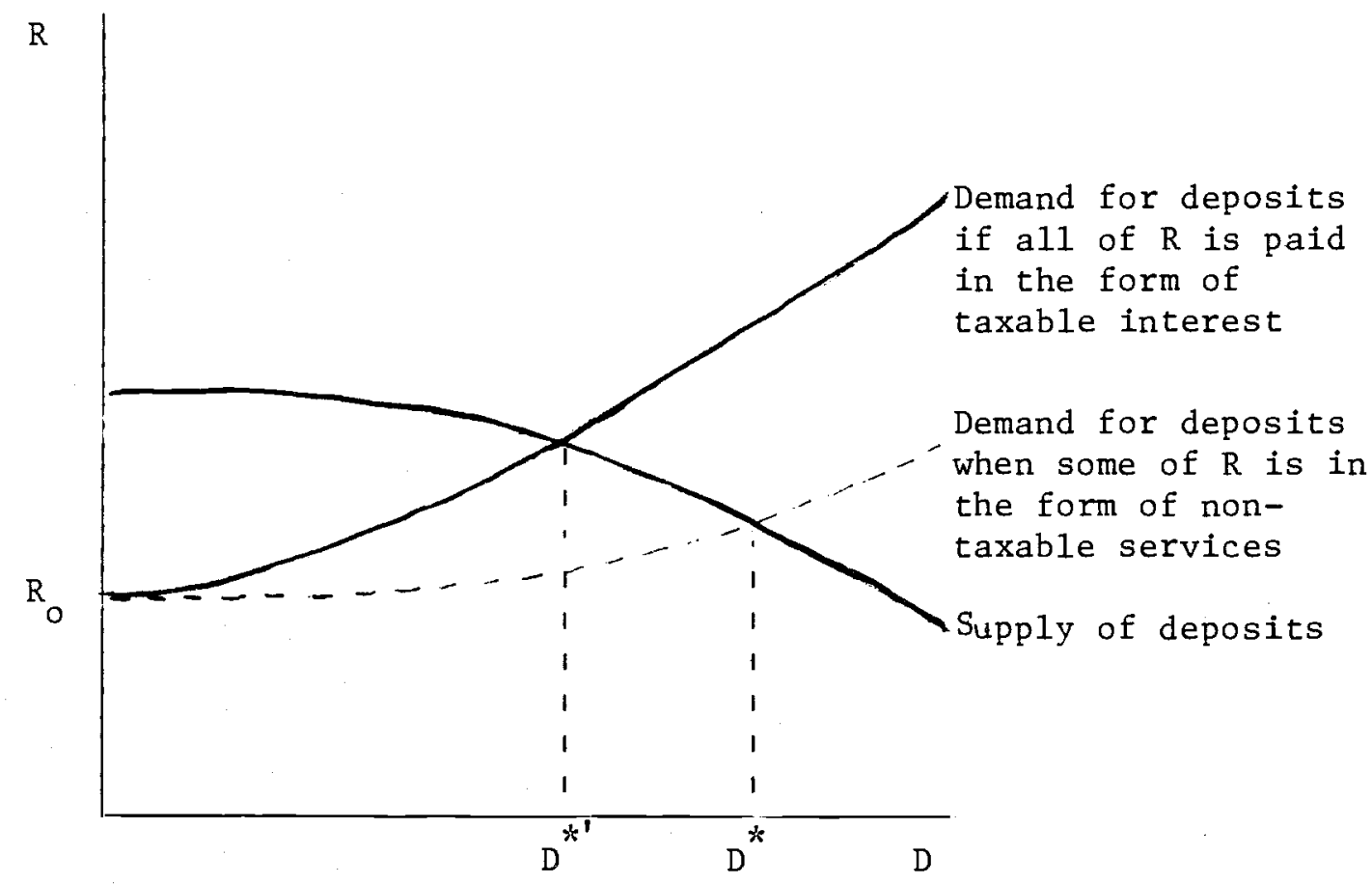

FIGURE 4

Payment of Part of $R$ in the Form of Non-Taxable Services Rather Than Taxable Interest Moves Equilibrium Deposit Level from $D^{* 1}$ to $D^{*}$. 

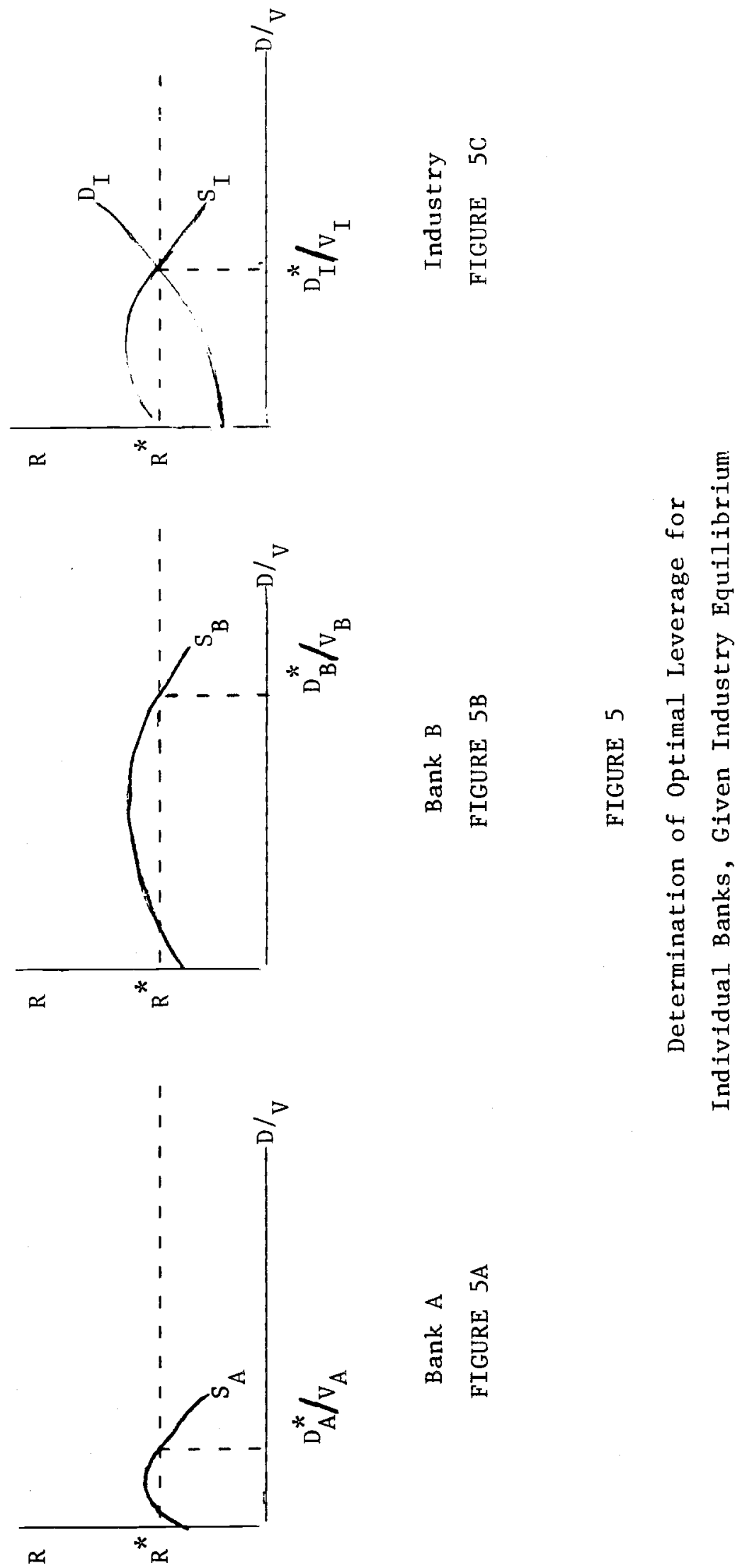

$$
\text { 4 }
$$


Footnotes

1. See Robichek and Myers [18] or Kraus and Litzenberger [10] for expositions of this theory. It is this theory that underlies the model of optimal bank capital structure in Buser, Chen and Kane [4]

2. In keeping with Barnea, Haugen and Senbet [1], we assume for simplicity that equity entails no agency costs. If that assumption were relaxed, the supply curve for debt would have a higher intercept and at least in the initial range, a more gentle downward slope, because up to some level; issuance of debt and retirement of equity would serve to reduce total agency costs.

3. Barnea, Haugen and Senbet [1], also emphasize that tax arbitrage operations (such as borrowing at the taxable rate and purchasing taxexempt bonds) must be prohibited or at least made costly to investors in order to maintain the upward slope of the demand curve for corporate debt. We implicitly make this same assumption in our analysis in Section II.

4. The impact of constraints on $R_{D}$ will be discussed further in Section II.B.

5. Commercial banks are not absolutely alone, of course, in their ability to offer such services. Money market mutual funds and thrift institutions, for example, compete with banks in providing such services, and to the extent that they do, the basic analysis of this section applies to them as well. Nevertheless, largely because of regulatory restrictions on other institutions, banks are unique in terms of the precise range of services that they offer. 
6. In the more realistic case in which investors could also choose corporate bonds, financial intermediary liabilities, and other investment vehicles, all securities markets would equilibrate simultaneously and the shape of the demand curve for deposits would reflect the availability of these substitute instruments. Our analysis in this section may best be thought of, then, as a model of equilibrium in the banking industry that is implicitly imbedded in a general equilibrium model.

7. As indicated in expression (4), whether or not the slope of the demand curve is flatter when part of $R$ is paid in the form of non-taxable services depends on how the marginal value of these services changes with the deposit level. The demand curve without services could not lie everywhere below the demand curve with services, for then banks would never provide services. There may be some point, however, where the demand curve with services crosses, and hence is steeper than, the demand curve without services. As long as this point occurs beyond $\mathrm{D}^{*}$ in Figure 4, the provision of services will tend to increase bank leverage.

8. The horizontal axis in Figure 5 is $\mathrm{D} / \mathrm{V}$, or deposits relative to the value of the bank. This yardstick is used to emphasize differing degrees of relative leverage. Since the total size, $V$, of each bank is held constant throughout the preceding analysis, changing the axis to $\mathrm{D} / \mathrm{V}$ does not necessitate any fundamental alterations.

9. This implication is generally in accord with empirical observation for commercial banks in the U.S. For instance, the average capital/ assets ratio for national banks with total assets over five billion 
dollars was 4.75 percent in 1978 compared with a ratio of 8.49 percent for national banks with assets less than 10 million dollars (see Dince and Fortson [6], p. 51). This finding is also consistent with empirical studies of bank costs, which generally report at least some range of economies of scale:

10. This flattening of the demand curve because of the greater flexibility that varying types of accounts offer to depositors is analogous to the flattening of the demand curve for bonds that occurs in Barnea, Haugen and Senbet [1], when the possibility of tax arbitrage is introduced. By combining bond purchases with tax arbitrage operations, individual investors, in effect, tailor the bonds to their own portfolio needs, and thus the increases in interest rates necessary to induce investors to purchase additional bonds are smaller than if tax arbitrage operations were prohibited.

11. It should be noted, however, that in the face of personal taxes a complete "unbundling" of services on deposits is unlikely. Because services are not taxable to investors, we would always expect banks to find it profitable to offer some amount of "free" or at least subsidized services and correspondingly reduced interest payments, even if the banks could offer any interest rate they wished.

12. This is similar to Black's [2] notion that in a frictionless world each investor would hold his own corporation for tax purposes. Thus "every corporation has a clientele of one investor, and chooses its capital structure to fit that investor's needs."

13. Implicit here is the notion that depositors place a value on bankproduced safety, for which "homemade" diversification does not provide 
a perfect substitute, as it does, say in standard corporate finance discussions of conglomerate mergers or firm diversification.

14. The association between higher dividends and higher personal tax rates on stock implicitly assumes that tax arbitrage operations, such as described by Miller \& Scholes [13], are costly for investors. 15. See Orgler and Wolkowitz [15], Figure 5.1 (p. 90).

16. Federa1 Reserve Bulletin, [3], Table 1.25 (p.A17).

17. The same, of course, holds for nonbank financial institutions, which are also typically more highly levered than nonfinancial corporations. 
References

1. Amir Barnea, Robert A. Haugen and Lemma W. Senbet, "An Equilibrium Analysis of Debt Financing Under Costly Tax Arbitrage and Agency Problems," Journal of Finance 36 (June 1981).

2. Fischer Black, "Taxes and Capital Market Equilibrium Under Uncertainty," Working Paper No. 21B, University of Chicago, May, 1973.

3. Board of Governors of the Federal Reserve System, Federal Reserve Bulletin 67 (April, 1981).

4. Stephen A. Buser, Andrew H. Chen and Edward J. Kane, "Federal Deposit Insurance,Regulatory Policy, and Optimal Bank Capital," Journal of Finance 36 (March, 1981), pp. 51-60.

5. Harry DeAngelo and Ronald W. Masulis, "Optimal Capital Structure Under Corporate and Personal Taxation," Journal of Financial Economics 8 (March, 1980), pp. 3-29.

6. Robert R. Dince and J. C. Fortson, "Bank Examination, Capital Adequacy and Risk," The Bankers' Magazine 163 (May-June, 1980), pp. 49-54.

7. Eugene F. Fama, "Banking in the Theory of Finance," Journal of Monetary Economics 6 (January, 1980), pp. 39-57.

8. Robert A. Haugen and Lemma W. Senbet, "The Insignificance of Bankruptcy Costs to the Theory of Optimal Capital Structure," Journal of Finance 33 (May, 1978), pp. 383-93.

9. Michael C. Jensen and William H.Meckling, "Theory of the Firm: Managerial Behavior, Agency Costs and Ownership Structure," Journal of Financial Economics 3 (October, 1976), pp. 305-60. 
10. Alan Kraus and Robert Litzenberger, "A State-Preference Model of Optimal Financial Leverage," Journal of Finance 28 (September, 1973), pp. 911-22.

11. Robert C. Merton, "An Analytic Derivation of the Cost of Deposit Insurance Loan Guarantees: An Application of Modern Option Pricing Theory," Journal of Banking and Finance 1 (June, 1977), pp. 3-11.

12. Merton H. Miller, "Debt and Taxes," Journal of Finance 32 (May, 1977), pp. 261-75.

13. and Myron S. Scholes, "Dividends and Taxes," Journal of Financial Economics 6 (December, 1978), pp. 333-64.

14. John J. Mingo, "Regulatory Influence on Bank Capital Investment," Journal of Finance 30 (September, 1975), pp. 1111-21.

15. Yair E. Orgler and Benjamin Wolkowitz, Bank Capital (New York: Van Nostrand Reinhold Co., 1976).

16. Sam Peltzman, "Capital Investment in Commercial Banking and its Relationship to Portfolio Regulation," Journal of Political Economy 78 (January, 1970), pp. 1-26.

17. John H. Pringle, "The Capital Decision in Commercial Banks," Journal of Finance 29 (June, 1974), pp. 779-95.

18. Alexander A. Robichek and Stewart C. Myers, "Problems in the Theory of Optimal Capital Structure," Journal of Financial and Quantitative Analysis 1 (June, 1966), pp. 1-35.

19. Anthony M. Santomero and Ronald D. Watson, "Determining Optimal Capital Standards for the Banking Industry," Journal of Finance 32 (September, 1977), pp. 1267-82. 
20. Kenneth E. Scott and Thomas Mayer, "Risk and Regulation in Banking: Some Proposals for Federal Deposit Insurance Reform," Stanford Law Review 23 (May, 1971), pp. 857-902.

21. Clifford W. Smith, Jr. and Jerold B. Warner, "On Financial Contracting: An Analysis of Bond Covenants," Journal of Financial Economic.s 7 (June, 1979), pp. 117-61.

22. Robert A. Taggart, Jr. and Stuart I. Greenbaum, "Bank Capital and Public Regulation," Journal of Money, Credit and Banking 10 (May, 1978), pp. $158-69$.

23. Jerold B. Warner, "Bankruptcy Costs: Some Evidence," Journal of Finance 32 (May, 1977), pp. 337-47. 